\title{
A construção do relato memorialístico em três contos contemporâneos
}

\author{
Benedita de Cássia Lima Sant'Anna
}

\section{SciELO Books / SciELO Livros / SciELO Libros}

SANT’ANNA, BCL. A construção do relato memorialístico em três contos contemporâneos. In: WEINHARDT, M., org. Ficções contemporâneas: história e memória [online]. Ponta Grossa: Editora UEPG, 2015, pp. 215-235. ISBN 978-85-7798-214-1. Available from SciELO Books $<$ http://books.scielo.org $>$.

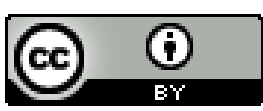

All the contents of this work, except where otherwise noted, is licensed under a Creative Commons Attribution 4.0 International license.

Todo o conteúdo deste trabalho, exceto quando houver ressalva, é publicado sob a licença Creative Commons Atribição 4.0. 


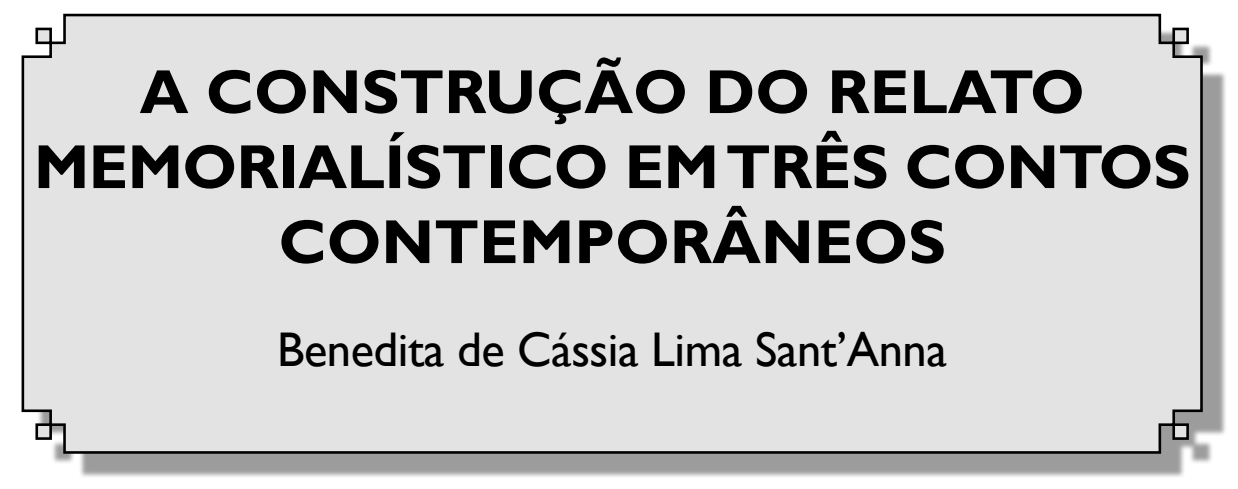

Memória consiste na habilidade do indivíduo de guardar acontecimentos, experiências e fatos por ele vivenciados e/ou a ele narrados e o relato memorialístico na sua capacidade de rever tais fatos e poder transmiti-los a si mesmo, em momentos posteriores, e, principalmente, em poder expor a outros, sobretudo às novas gerações. A transmissão desse tipo de relato resulta da prática do indivíduo de analisar suas próprias memórias, ou as que lhe foram contadas, por intermédio de um exercício árduo de interiorização e atualização que o levará à busca por uma "verdade", ou seja, por uma nova forma de compreensão dos eventos ocorridos, sentidos, retratados e revistos. Interessa-nos, neste texto, refletir acerca do modo como os relatos de memória são construídos e aparecem ficcionalmente narrados nos contos "Animais", de Michel Laub; "Você tem dado notícias?", de Leandro Sarmatz e "Violeta", de Miguel Del Castillo, contribuindo para a existência de um diálogo, ainda que latente, entre esses contos e realidades históricas.

Tais contos foram selecionados entre os constantes do nono número da revista Granta - publicação literária britânica, fundada em 1889 por estudantes da Universidade de Cambridge como uma publicação destinada a jovens autores, e reformulada em 1979, quando ganhou o formato que ainda mantém. Atualmente, conta com versão em inglês, tem periodicidade trimestral, e versão em mais de sete países: Espanha, Itália, Bulgária, Brasil, China, Noruega, Suécia e Portugal. Esse número, lançado em 2012, dedicado à publicação d'"Os melhores jovens escritores brasileiros", traz entre as vinte narrativas que o compõe, alguns contos em que o passado histórico apresentase como um dado relevante, aspecto raramente encontrado em conto, devido 
à própria linearidade e extensão do conto. Escolhemos, dentre os contos lidos, aqueles em que a ficcionalização da história despertou a nossa curiosidade interpretativa.

No conto "Animais", de Michel Laub, a memória e/ou relatos de mortes de amigos (animais de estimação e colegas de infância), sempre associada à presença e importância da figura paterna na vida do narrador protagonista, contrapõem-se a ausência dessa figura na vida do seu progenitor, tendo em vista que esse teve a família separada e foi privado do convívio com seu pai (avô do narrador), em decorrência da perseguição aos judeus durante a Segunda Guerra mundial.

Em “Você tem dado notícias?", de Leandro Sarmatz, a menção de acontecimentos históricos como a perseguição aos judeus também é aludida: descendente de judeu, nascido e criado no Brasil, o protagonista do conto não aceita as regras e tradições impostas por esses e, buscando distanciamento familiar, suposta liberdade profissional e sexual, abandona a esposa e o filho recém-nascido.

O abandono ou mesmo a tentativa de distanciamento das origens e do passado familiar, ainda que por motivações diversas das do narrador protagonista criado por Leandro Sarmatz, é um dos aspectos verificados no conto "Violeta", de Miguel Del Castillo. Nesse conto, acontecimentos relacionados à ditadura civil-militar ocorrida no Uruguai entre os anos 1973 a 1985, após terem sido abandonados e/ou silenciados temporariamente em conversas familiares, passam a ser revivenciados pelo narrador Miguel Angel, personagem secundária da narrativa, que, ao descobrir a origem de seu nome sente-se atraído pela história de sua família e, consequentemente, por fatos, ou melhor, por vestígios de fatos históricos ocorridos no Uruguai.

As "realidades históricas" ou "acontecimentos históricos" mencionados nos contos trouxeram, como se sabe, muito sofrimento. O terror antissemita, por exemplo, golpeou "suas vítimas de acordo com suas características perceptíveis, sobretudo segundo sua origem étnica já assinalada de longa data, no caso dos judeus" (MAIER, 2002) e permanece na memória individual e 
coletiva do Ocidente, tanto dos que foram vítimas de tal perseguição, como dos seus descendentes e dos descendentes daqueles que presenciaram e/ou participaram do holocausto. Por ser motivo de profundos sentimentos de vergonha, essa memória às vezes é silenciada, conservando-se como "um tabu nas histórias individuais na Alemanha e na Áustria, nas conversas familiares e, mais ainda, nas biografias dos personagens públicos" (POLLAK, 1989), antigos nazistas ou simpatizantes do regime. Os próprios judeus e seus descendentes, por razões diversas e até difíceis de delimitar, em muitas ocasiões também silenciam diante da memória de acontecimentos terríveis que evidenciam a perseguição sofrida.

Observa-se que de forma velada ou desvelada o holocausto permanece indelevelmente gravado na memória ocidental, enquanto a ditadura uruguaia, seja pela menor abrangência territorial, seja pelo fato de estar inserida e repercutir na vida de uma única nação, ademais ao fato de ter vitimado um número menor de pessoas, insere-se apenas na memória de uma pequena parte do ocidente, ou seja, é lembrada e discutida por aqueles que presenciaram o movimento, ou mesmo por aqueles que se sentem, por algum motivo, atrelado a ele. O Uruguai, no máximo a América Latina, é o limite das memórias da ditadura militar.

Como pretendemos verificar o modo como o passado histórico é apresentado ou sutilmente aludido em cada um dos contos citados, por intermédio de apontamentos relacionados ao relato memorialístico neles presentes, daremos início às nossas observações refletindo acerca da linguagem utilizada por Michel Laub na construção do conto "Animais".

\section{"Animais", de Michel Laub}

Se a humanidade construiu outros tempos, mais rápidos e violentos que os das plantas e animais, é porque dispõe deste extraordinário instrumento de memória e de propagação das representações que é a linguagem.

(Pierre Lévy) 
A linguagem, seguindo a sintaxe e prosódia própria de uma criança que tem a vida direcionada pelas circunstâncias, pelos acontecimentos, pelo enredo, é um dos pontos mais significativos desse conto de Michel Laub. Nota-se que o escritor ora utiliza orações coordenativas assindéticas, ora utiliza orações coordenativas sindéticas, sobretudo aditivas, para narrar suas recordações. Essa "faceta" da narrativa reveste-se de um aspecto camaleônico, pois ao mesmo tempo em que insinua ao leitor simplicidade ou até mesmo ingenuidade, dá graça, leveza e consistência ao enredo, criando uma relação de intensa cumplicidade com o leitor.

Em "Animais", a escolha por esse tipo de linguagem ressalta o quanto os acontecimentos anteriores, vivenciados, principalmente, na infância do narrador, permanecem presentes em sua vida, como marcas presas ao tempo que constituem verdadeira matéria-prima da qual ele (o narrador protagonista), já adulto, lança mão para aproximar-se do leitor, transformando-o em uma espécie de seu confidente.

É a esse leitor/confidente que o narrador expõe suas lembranças: discorre sobre seus animais de estimação desde a morte de seu cachorro denominado Champion, "morto pelo dobermann do vizinho", passando pela aquisição e perda de outros animais de estimação "um hamster, um pato, um gato e um segundo gato" (LAUB, 2012, p. 13).

A aquisição e perda desses animais constituem indícios, vestígios de pistas que nos ajudam a compreender o modo como os sentimentos do narrador (amizade, amor e dor) estão tacitamente presentes no conto. O primeiro deles, o cachorro Champion é aquele que dá impulso ao ato de rememoração do narrador personagem. Presente em toda a narrativa, Champion dará início e término a essa, mostrando um lado obscuro do narrador, no qual o menino, próximo de se transformar metaforicamente em lobo, trama a morte do dobermann que teria causado o falecimento de seu cão:

Um cachorro morre de várias maneiras. Ele pode contrair raiva, cinomose, parvovirose. Pode ter hepatite e câncer. Pode tomar um tiro ou se intoxicar com uma planta. Ou então você pode pegar uma garrafa de vidro, enrolar no jornal, um dia úmido na garagem, a 
casa toda em silêncio, e pisar em cima do jornal várias vezes até os cacos ficarem bem pequenos. Alguns, quase invisíveis. Aí você pega um por um desses cacos, espeta num pedaço de carne crua, dos três lados e sobre toda a superfície, de forma que o pedaço fique pesado e com a textura de areia. Aí você sobe as escadas, atravessa a sala, abre a porta, atravessa o jardim, chega perto da cerca vizinha, o mais próximo que consegue por causa dos arbustos, o prato preferido de qualquer cachorro em qualquer lugar e qualquer época, e joga a encomenda para o outro lado (LAUB, 2012, p. 22).

Nota-se que o plano é revelado pelo protagonista, como se ele estivesse falando diretamente ou confessando algo ao leitor, algo que não pode nem deveria ser confessado. Há, neste momento, uma ruptura no discurso memorialístico, ou seja, nele o narrador apresenta ao seu interlocutor (leitor) uma receita, uma hipótese, uma possibilidade de acontecimento. Ocorre a sugestão de algo que pode ou não ter ocorrido, trata-se, portanto, de um pensamento, não necessariamente de um fato consumado. A possibilidade de realização ou não do fato é deixada a critério da interpretação do leitor, a quem cabe desvendar o episódio sugerido, atribuindo a esse significado, pois o menino estava "tão próximo de tomar uma decisão" (matar ou não o dobermann do vizinho coreano) enquanto o pai "esperava pela resposta do lobo" / menino (LAUB, 2012, p. 23).

O segundo animal de estimação referido pelo protagonista é o hamster, que ganhou após a morte de Champion, mas a esse é reservado apenas um parágrafo de suas memórias, no qual menciona o modo como o alimentava e, posteriormente, relembra as circunstâncias em que morreu. A referência a essa nova morte é parte da teia de lembranças e perdas que vão se configurando no desenrolar do conto. Entretanto, a lembrança mais marcante para o protagonista parece ter sido a morte de Champion:

Minha irmã chorou a noite toda por causa de Champion. Meu pai foi ao quarto dela várias vezes, eu ouvia os passos dele como que arrastando as pernas e lembrava de nossa conversa à tarde, ele pedindo que eu fosse forte, nós tínhamos que poupar a minha irmã, eu já era grande e era o irmão mais velho e é isso o que um irmão mais velho faz. [...] E nunca mais, nem na morte de Victor, nem na de Marcelo, nem na do outro Marcelo, nem mesmo na do meu pai e 
na cerimônia de inauguração do túmulo, até porque eu não chorei em nenhum desses eventos, uma lágrima que fosse, uma vida inteira sem derramar uma lágrima [...] (LAUB, 2012, p. 22).

Além de ser o iniciador da teia de lembranças e perdas, o cachorro Champion, ou melhor, a morte do cachorro Champion, possibilita ao narrador protagonista ter uma visão mais plena acerca da realidade, da forte presença do pai - "Quem me falou da morte de Champion foi meu pai" (LAUB, 2012, p.14) -, da proximidade e amizade que mantinha com ele, de aspectos relacionados à personalidade de seu progenitor, bem como de atitudes desse que ainda não havia presenciado:

[...] e um dia meu pai estava ao telefone e eu parei atrás da porta e ele estava contando a história toda, com todos os detalhes, antes, durante e depois do ataque do dobermann, e então ele começou a dizer merda, que merda que foi isto. Foi a única vez em que ouvi ele tremendo a voz. No final era quase um sussurro. E nunca mais ele comentou o episódio, [...] (LAUB, 2012, p. 21).

O pai silenciado pela ausência de solução e/ou resposta à indignação que sente com a falta de comprometimento do vizinho coreano, dono do dobermann, é expressão de paciência e responsabilidade. Figura nas lembranças do narrador protagonista como presença constante, como aquele lhe transmitiu educação e saberes:

Meu pai me ensinou a dirigir, nadar, usar solda, montar uma caixa de luz que dava para quatro lâmpadas a três metros de distâncias, e com isso montamos um trem fantasma na garagem de casa. Foi ele que me levou para tomar vacina tríplice. Foi com ele que andei de avião a primeira vez. Foi ele que abriu uma conta no banco para mim, e me ensinou as primeiras palavras em inglês, e trouxe as revistinhas de faroeste que me ajudaram a pegar gosto pela leitura e mais tarde virar escritor (LAUB, 2012, p. 18).

No conto "Animais", o pai também é aquele de quem o narrador lança mão para ativar suas lembranças e elaborar seu ato de rememoração. A partir do modo como o descreve, o narrador confessa a si e revela ao leitor que as imagens que constrói de seu progenitor mesclam realidade e ficção, ficção e realidade: 
[...] Nos romances que escrevi retratei meu pai de várias formas: como judeu marcado pela memória de guerra, como personagem secundário na história do acidente com a rede, como homem que dá a pior notícia da vida do filho antes de um jogo de futebol. Tudo verdade e tudo mentira, como sempre na ficção, e já pensei muito no porquê de ter sempre escrito sobre ele, e se quando ficar velho vou confundir a memória dele com a memória registrada nesses livros: os fatos que escolhi contar ou não, os sentimentos que eu tinha ou não, quem foi meu pai de verdade e o que eu me tornei ou não por causa disso, ou apesar disso, ou independentemente disso, a história que por várias razões começa no espetáculo de balé depois da morte de Champion (LAUB, 2012, p. 20).

Observa-se que a experiência do vivido funde-se com a experiência do olhar, no instante presente daquele que narra. A imagem do pai, constantemente atualizada pelo ato memorialístico do narrador protagonista, coloca em evidência o papel da memória em processo, composta tanto da experiência oriunda do passado de cada um (do narrador e do pai), atualizado pela rememorização do narrador, quanto da própria apreensão que esse tem acerca do seu presente e de uma suposta expectativa com relação ao futuro, tendo em vista que "o retorno do passado nem sempre é um momento libertador da lembrança, mas um advento, uma captura do presente" (SARLO, 2007, p. 9).

Nesse conto, a memorização - modalidade do ato de fazer memória que, segundo Ricoeur, "consiste em maneiras de aprender que encerram saberes, habilidades, poder-fazer, de tal modo que estes sejam fixados" - e a rememoração - modalidade do ato de fazer memória em que "enfatiza-se o retorno à consciência despertada de um acontecimento reconhecido como tendo ocorrido antes do momento em que esta declara tê-lo sentido, percebido, sabido" (RICOEUR, 2007, p. 73) -, são encontradas no discurso memorialístico do narrador protagonista. Este remete à primeira modalidade nos momentos em que narra fatos ocorridos na sua infância, como a morte de seu cachorro Champion, algumas das conversas que manteve com o pai e ao mencionar o teatro de marionetes que este fez para ele e para a irmã, por causa do trauma que um fato noticiado na televisão, envolvendo ariranhas, causara em ambos etc. Já a rememoração aparece nos momentos em que revê analiticamente 
suas memórias, quando, por exemplo, salienta a compreensão de que nunca havia falado com o pai acerca da infância desse:

[...] hoje me dou conta de que nunca conversei com meu pai sobre a infância dele, os colegas da escola que talvez tenham ficado na Alemanha, alguns ou todos indo parar em campos de concentração, ou sobre as lembranças que ele tinha das ruas e da cidade e do país que foi arrasado nos anos seguintes (LAUB, 2012, p. 17).

Nota-se, no trecho citado, o relato de uma consciência que aflora, acerca de um acontecimento ocorrido anteriormente. Trata-se, portanto, da modalidade de fazer memória definida por Paul Ricoeur como rememoração, em que "A marca temporal do antes constitui, assim, o traço distintivo da recordação, sob a dupla forma da evocação simples e do reconhecimento que conclui o processo de recordação" (RICOEUR, 2007, p. 73).

Assim sendo, pode-se afirmar que o protagonista do conto "Animais," ao evocar seu passado, as conversas que manteve com o pai, percebe no silêncio desse o sinal distintivo dos sofrimentos e perdas vivenciadas por seu progenitor, em decorrência do regime nazista ${ }^{1}$ instaurado na Alemanha por Adolf Hitler:

Meu pai veio da Alemanha por causa do nazismo, em 1937, aos seis anos, junto com a mãe. Meu avô migrou com a filha mais velha para Israel. Meu pai só foi ver a irmã em 1970, e meu avô ele nunca mais viu porque nessa viagem, e ele foi porque meu avô estava no hospital, com câncer no último estágio, nessa viagem meu avô se recusou a recebê-lo. Meu avô considerava meu pai uma página virada. A razão é que meu pai, ainda criança, não teria respondido as cartas que meu avô mandou para o Brasil. Meu pai só me contou isso em 2007, eu já morando em São Paulo, numa conversa de dois minutos enquanto esperávamos um táxi na Alameda Itu (LAUB, 2012, p. 14-15. Grifo do autor).

O fato do pai só revelar ao filho, tardia e brevemente, acontecimentos relacionados à sua história de vida, explica-se por tratarem de "lembranças

\footnotetext{
${ }^{1}$ Durante o regime nazista, além dos judeus, as autoridades alemãs também destruíram grandes partes de outros grupos considerados 'racialmente inferiores' como, "os ciganos, os deficientes físicos e mentais, e eslavos (poloneses, russos e de outros países do leste europeu)”. Também perseguiram indivíduos por causa de atitudes políticas, ideológicas e comportamentais que assumiam, dentre esse, "os comunistas, os socialistas, as Testemunhas de Jeová e os homossexuais”. (Enciclopédia do Holocausto. Disponível em: <http://www.ushmm.org/wlc/ptbr/article.php?ModuleId=10005143>. Acesso em: 30 out. 2014.).
} 
traumatizantes", ou seja, "lembranças que esperam o momento propício para serem expressas". Segundo Pollak, enquanto isto não ocorre, tais lembranças ficam "confinadas ao silêncio", posteriormente, serão "transmitidas de uma geração a outra oralmente" (POLLAK, 1989).

Ainda sobre o silêncio do progenitor, importa mencionar, citando o mesmo teórico, particularmente o momento em que esse se refere aos sobreviventes dos campos de concentração, que o "silêncio sobre o passado está ligado em primeiro lugar à necessidade de encontrar um modus vivendi com aqueles que, de perto ou de longe, ao menos sob a forma de consentimento tácito, assistiram à sua deportação" (POLLAK, 1989). No caso específico do conto de Michel Laub, com aqueles que estão ou serão incluídos a esse passado por descendência, ou melhor, por herança, por legado.

Neste universo narrativo em que vestígios de um passado histórico, presente e futuro se enlaçam, os fatos ocorridos no passado do narrador protagonista — como, a morte de seu amigo Victor, em 1987, "preso em uma rede de pesca enquanto surfava"; a morte de seu amigo Marcelo, em maio de 1992, assassinado "por um bandido quando saía do carro", a morte de seu outro amigo chamado Marcelo que, "recém-empossado como promotor de justiça em Santa Rosa, interior do Rio Grande do Sul", levou "seis tiros de um policial bêbado"; a morte do seu primeiro gato devido a um atropelado; a morte do Champion, bastante referida neste texto e no conto; a morte e o enterro do pai, dentre outros fatos, como a apresentação de balé da irmã e a menção do afastamento de seu segundo gato, levado por sua ex-esposa na separação (LAUB, 2012) —, integram o método de aquisição e, principalmente, de reconhecimento de saberes e experiências que se concretizam graças à narração, tendo em vista que "a linguagem liberta o aspecto mudo da experiência, redime-a de seu imediatismo ou de seu esquecimento e a transforma no comunicável, isto é, no comum" (SARLO, 2007, p. 24).

Com essa suposta despretensão de significado atribuído ao aspecto comum do discurso narrativo, o protagonista do conto "Animais" refere-se a suas peregrinações em bares paulistanos, em decorrência da saída de sua mulher de casa, bem como as consequências oriundas desse fato e de seu 
novo estilo de vida: "Eu perdi um emprego por causa disso. Eu comecei vários relacionamentos e nenhum deu certo por causa disso" (LAUB, 2012, p. 20).

Tais declarações introduzem novos elementos à narrativa, fatos que pertencem a momentos mais próximos ao presente, lembranças que, aliadas às anteriores, motivam e/ou levam o narrador protagonista a adotar o silêncio e a reclusão: "Eu nunca mais falei com minha ex-mulher, nem com nenhuma das namoradas que tive, nem com a maioria dos colegas, de faculdade, de trabalho, os amigos que fiz ao longo de quarenta anos e que eu não sei mais onde moram, o que fazem, se estão vivos" (LAUB, 2012, p. 20).

A reclusão e silêncio do protagonista em relação a seus amigos e exnamoradas ajudam a encobrir a necessidade de uma reflexão acerca de suas escolhas e de seu comportamento com essas pessoas. Tal reflexão só seria possível por meio do contato e do diálogo, ou melhor, por meio do ato de rememoração desse contato. Entretanto, no conto "Animais", a preferência do narrador é claramente atribuída ao passado mais remoto (aos animais e amigos de infância) e às recordações e lembranças que surgem com e/ou acerca da figura do pai:

Minha mãe gosta de falar do meu pai, para ela não é algo mórbido, pelo contrário, e eu gosto também porque as lembranças dela volta e meia incluem algo que eu não sabia ou tinha esquecido: a vez em que ele ganhou um prêmio do Conselho de Engenharia, em que resolveu fazer churrasco e acendeu o fogo com um secador elétrico, em que montou um teatrinho de massa de modelar por causa dos meus sonhos com a ariranha (LAUB, 2012, p. 17).

Notar-se-á que nesse conto, diferentemente do que veremos a seguir no conto "Você tem dado notícias?", de Leandro Sarmatz, a trajetória de vida do pai do narrador é lembrada com entusiasmo. No conto "Animais" o pai até pode ser o portador de notícias ruins, mas é também aquele que interage com essas transformando-as em algo menos traumatizante. É um bom exemplo de homem e de vida. Enquanto que no conto de Leandro Sarmatz, os três progenitores (o sogro, o narrador e o pai do narrador) não são descritos e/ ou não podem ser interpretados como modelos paternos a serem seguidos. 


\section{"Você tem dado notícias?", de Leandro Sarmatz}

O narrador de "Você tem dado notícias?" é um homem doente, já desenganado, que regressa à cidade de origem depois de um longo período, porque sente a necessidade de ter notícias daqueles que ele próprio havia deixado. Neste retorno, narra ao filho trechos de sua vida: período em que frequentou a sinagoga, o namoro com a ex-mulher, a morte de seu pai, faz alusão a casos extraconjugais e revela o que fez no período em que esteve ausente. Isto sem demonstrar arrependimento ou sem se sentir culpado pelas escolhas feitas e, consequentemente, pelo abandono da família.

Percebe-se, entretanto, que ele tem consciência dos erros cometidos e da parcela de culpa que cabe a si e aos outros acerca da influência que exerceram para que ele optasse por mudar a trajetória de sua vida - "Todo mundo paga um preço por suas escolhas, e eu tive contas a acertar comigo mesmo. Sua mãe não escaparia dessa economia primordial dos sentimentos" (SARMATZ, 2012, p. 219-220). Tal fato pode ser comprovado pela linguagem dura e ao mesmo tempo comum de alguém que, apesar de estar num momento derradeiro, é capaz de analisar o presente e rever o passado pessoal num nível de reflexão mais avançado.

Não espero que você tire o chapéu para mim. O que fiz certamente trouxe consequências nefastas para você, assim como para o resto da família em menor medida. O homem que foge, o pai que desaparece, o sujeito sem coração. Honestamente, se eu não estivesse assim, tão próximo da morte, eu não teria tido a coragem de voltar a este passado tão distante (SARMATZ, 2012, p. 223).

Esse processo reflexivo em que o narrador consegue "atribuir diretamente a memória à esfera" de si mesmo, por meio de um distanciamento íntimo que "passa despercebido a ponto de não ser notado" como tal ou mesmo como lembrança, normalmente, caracteriza-se por uma denegação da distância que, de acordo com o "vocabulário de Husserl", pode ser interpretado como o aspecto habilitado para "distinguir o noema, o 'que' é lembrado, da noese, o ato de lembrar-se, refletido em seu 'quem"' (RICOEUR, 2007, p. 136). 
Trata-se, portanto, de um traço diferenciador, mas não único, da memória pessoal do narrador protagonista desse conto. Aliás, ele apresenta outras características passíveis de serem encontradas em níveis avançados de reflexão, como o "emparelhamento', que atua na percepção de outrem" como uma operação silenciosa. Tal operação, no contexto narrativo do conto “Você tem dado notícias?", pode ser denominada de Einfühlung, vocábulo que, segundo Paul Ricoeur, designa essa espécie de imaginação afetiva pela qual nos projetamos na vida de outrem (RICOEUR, 2007, p. 137).

Ao projetar-se na vida da ex-esposa, do sogro, do pai e do próprio filho, o narrador protagonista preenche, por meio do exercício de atualização memorialística, lacunas de seu passado, as quais o filho provavelmente desconhecia e, ele (o narrador), utiliza para amenizar seus atos, redimir da culpa e atribuir ao desejo e a liberdade sexual as únicas lembranças positivas de seu matrimônio:

O fato é que nos casamos no início de 1970. Entramos na sinagoga menos de um mês depois da formatura dela no curso de magistério. A professorinha jovem, inteligente, articulada e gostosa, a leitora de Hesse e colecionadora dos discos de Chico Buarque, era agora uma esposa.

O início do nosso casamento foi como todos os outros: intenso, cheio de fogo, eu voltando correndo do trabalho no jornal para chegar em casa a tempo de vê-la acordada e acesa para mim (SARMATZ, 2012, p. 219-220).

A ex-mulher, inicialmente desejada, atua como elemento de conflito a partir do momento em que, por meio do reconhecimento reflexivo do passado, o narrador protagonista ressalta nela motivações diversas as esperadas em uma mulher que se casa por estar apaixonada pelo marido.

Às vezes acho que ela ficava mais feliz pelo macarrão do que pela própria trepada. Porque naquele tempo até uma refeição podia ser uma manifestação de independência em relação aos laços familiares. À noite, na casa da mãe dela, eles sempre tinham que tomar uma sopa de galinha. Era o único prato. Sem variações. A sua avó, a mãe dela, usava um mesmo frango a semana inteira para dar sabor ao caldo dourado - ela, seu avô e seu tio comiam as cenouras e as batatas, mergulhavam o pão de centeio naquelas ilhas de gorduras dissolvida, mas eram proibidos de tocar num pedaço daquela pobre 
galinha escaldada tantas e tantas vezes. Só no jantar de sexta-feira lhes era permitido comer a carne, a essa altura mera sombra, sem graça ou sabor, da galinha que fora despejada na panela no início da semana (SARMATZ, 2012, p. 220).

Dessa forma, a ex-mulher ao casar-se com ele desejava supostamente, entre outros motivos, libertar-se de hábitos familiares. E, o abandono, seria o preço pago por isso e por ter permitido e até mesmo possibilitado que a família interferisse na vida conjugal de ambos. Tal interferência constitui ponto de desordem e opressão:

A família dela cada vez mais presente em nossas decisões cotidiana, o pai dela iniciando a infame campanha para que eu abandonasse qualquer veleidade pessoal e fosse trabalhar com ele no ramo dos guarda-chuvas, os elementos ancestrais da vida emocional judaica (como a paranoia e a culpa) promovendo um ataque diário para ocupar qualquer centímetro que porventura ainda estivesse disponível da nossa independência (SARMATZ, 2012, p. 220-221).

A busca pela independência, impossível de ser alcançada naquele seio familiar de tradição judaica, ao qual ele pertencia, mas desejava desvincular-se, atinge seu ápice por ocasião do nascimento do filho e da percepção de que se continuasse ali, poderia reproduzir para si um modelo de vida semelhante ao vivido pelo pai - fiel a esposa a quem parecia não suportar, sócio do irmão que odiava e cercado por pessoas pelas quais não nutria nenhuma simpatia - faz o narrador protagonista "decidir acabar com tudo antes que tudo acabasse" com ele (SARMATZ, 2012, p. 216).

No entanto, a saída de casa e o abandono do filho não possibilitaram o esquecimento e, sem esse, era de se esperar que a procura pela liberdade ficasse comprometida, como de fato ficou. Preso ao passado e aos que a esse pertencia, o protagonista não obteve o sucesso e a emancipação esperada: “[...] perambulei para lá e para cá, estive em lugares cuja memória eu não gostaria de perpetuar, tive períodos de relativa bonança e outros (como agora, enquanto vou encarando aquela que se cristaliza como a fase terminal da minha vida) bem miseráveis" (SARMATZ, 2012, p. 224). 
Assim sendo, conclui-se que, mesmo após ter saído do espaço em que se considerava prisioneiro, o narrador é envolto por uma prisão que, apesar de ser silenciada pelas novas escolhas, não poderá ser negada, pois "cada pessoa singular está realmente presa; está presa por viver em permanente dependência funcional de outras; ela é um elo nas cadeias que ligam outras pessoas, assim como todas as demais, direta ou indiretamente, são elos nas cadeias que as prendem" (ELIAS, 1994, p. 23).

Preso ao presente escolhido e ao passado deixado e renegado, o protagonista, apesar do distanciamento da família, não deixou de ser o homem que na adolescência "tirava uns trocos entoando música litúrgica numa pequena sinagoga", um rapaz da primeira geração judaica aqui nascida, um legítimo brasileiro, influenciado pelos fatos ocorrido após a segunda guerra mundial: o rock como arte, a ditadura no Brasil, a pílula, a sexualidade e a "recusa ao mundo dos pais. Novos costumes sepultando hábitos seculares. O filho do imigrante fingindo ser mais nativo do que aqueles que estão no país há duzentos anos" (SARMATZ, 2012, p. 219).

O resultado desse fingimento e, particularmente, das ações praticadas para denegar costumes, laços e intromissões familiares levou o narrador protagonista ao isolamento e ao fracasso pessoal, o que se constata por intermédio do exercício de rememoração por ele realizado, quando estabelece escolhas específicas para fixar assiduamente sua necessidade de granjear a liberdade por ele imaginada, mas que, de certa forma, nunca foi conquistada, pois, na sua busca por mudanças, empenhou-se tanto para se desvencilhar do passado - do já mencionado exemplo de vida paterno, da supremacia do sogro, da herança "tradicionalmente" judaica, da qual esse é apresentado como o maior mantenedor - que acabou sendo oprimido pelos próprios atos, pelo desejo e pela ausência de um direcionamento capaz de levá-lo de fato a um modo de vida mais livre: independente intelectual, sexual e financeiramente.

Com câncer em fase avançada, sozinho e com dificuldades financeiras, ele precisa do auxílio do filho - "espero que já no próximo segundo você saque certa quantidade de dinheiro da carteira" - e a atualização reflexiva acerca do passado, bem como o regresso ao lugar de origem, "voltar para ver como estavam 
as coisas, quem ainda está de pé e quem já padeceu. Um tipo de curiosidade mórbida, com a única diferença de que sou eu a carniça sendo observada no meio-fio" (SARMATZ, 2012, p. 229), tornam-se algo desejado e inevitável.

O retorno às origens também está presente no conto "Violeta", de Miguel Del Castillo. Entretanto, nesse conto, o retorno não é motivado pela curiosidade, pela necessidade de retratação consigo e com os outros ou pela ausência de recursos monetários, mas pela possibilidade de reconhecer-se como indivíduo associado a uma história que permanece na memória coletiva de sua família e da sociedade pertencente ao país onde os fatos lembrados, revividos e reconstruídos ocorreram.

\section{“Violeta”, de Miguel Del Castillo}

No conto "Violeta", de Miguel Del Castillo, o regime ditatorial uruguaio - marcado historicamente pela proibição dos partidos políticos, pela ilegalidade dos sindicatos, pela censura à imprensa, pela perseguição, pela prisão, pelo desaparecimento e pelo assassinato de opositores, bem como pelo processo de deterioração social e política geradora de conflitos, aos quais se incluem a luta armada de guerrilhas urbanas - ganha cada vez mais significado, à medida que o narrador, por intermédio de um processo memorialístico, revitaliza e revivencia acontecimentos que antes lhe eram desconhecidos, como a escolha de seu nome, as experiências vividas por familiares no Uruguai e a língua materna desses, que para ele constitui uma herança negada:

Miguel Angel foi um dos primos do meu pai, tupamaro que desapareceu na ditadura uruguaia. Meu nome de batismo, portanto, é uma homenagem. Por muitos anos ignorei a história da minha família, os 22 anos que meu pai passara em Montevidéu antes de se mudar para o Rio, Miguel Angel etc. Aprendi sozinho o espanhol que nunca fizeram questão de me ensinar (CASTILLO, 2012, p. 243).

O processo de apropriação do passado até então ignorado pelo narrador personagem inicia-se com a rememoração, na qual a ênfase é dada à consciência 
despertada pelos acontecimentos ocorridos antes do momento em que o personagem os percebe e entende.

Ao referir-se a origem do nome, ou melhor, ao tomar consciência de que a escolha de seu nome foi uma forma de seu pai homenagear o primo tupama$\mathrm{ro}^{2}$, o narrador inicia uma busca pelo passado familiar que o leva a desvendar momentos relacionados ao passado social uruguaio, por meio de um exercício de atualização desse passado. As lembranças a ele narradas por familiares vão se configurando como verdadeiros "itinerários" do campo dos acontecimentos vivenciados pela família. Miguel Angel separa, recorta e compõem uma visão ainda que parcial do passado e descreve a história familiar de acordo com a sua experiência de vida e com a escolha feita daquilo que seus parentes viram, vivenciaram e, muito posteriormente, narraram a ele.

O retorno ao passado e a origem do nome que lhe foi dado apresenta-se no conto como a procura pela própria identidade, pela identidade familiar e, ademais, pela identidade social uruguaia, país pelo qual o personagem demonstra grande interesse, mas que lhe causa um sentimento de profunda tristeza:

[...] Olhando pela janela do avião no pátio, penso na melancolia que esse país sempre me causou, mas por quê? Parece-me que não são os prédios do centro antigo, nem o sol da tarde nos bancos de pedra vermelha da rambla. Talvez sejam as pessoas e tudo que já me disseram, que o Uruguai era assim mesmo, ah o tempo em que o Zitarrosa ainda estava vivo etc., os ex-tupamaros (CASTILLO, 2012, p. 248).

Nota-se que a alusão a quadros sociais uruguaios, os quais não fizeram parte da infância do narrador, enfatiza no conto a existência de lembranças que por muito tempo foram silenciadas. Entretanto, essa ausência de informação

\footnotetext{
${ }^{2}$ Movimento de Libertação Nacional - Tupamaros (MLN-T), existente nas décadas de 1960 e 1970, antes e durante a ditadura civil-militar no Uruguai, iniciada em 1973 e encerrada em 1985. Foi uma organização marxista-leninista uruguaia de guerrilha urbana, composta por universitários, técnicos e profissionais liberais. Entre as ações praticadas por essa organização destacam-se as investigações dentro de grandes corporações que tinham por objetivo encontrar documentos que comprovassem a corrupção governamental. Todavia, seus membros também realizaram assaltos a bancos, clubes de armas etc. e, segundo alguns historiadores, parte do dinheiro angariado na prática de tais atos foi distribuída aos pobres em Montevidéu. No final dos anos 1960, o grupo envolveu-se também em propaganda armada, assassinatos e sequestros de políticos, dentre esses, o do cônsul brasileiro em Montevidéu, Aloísio Gomide (ALTMAN, 1973).
} 
sobre o passado, geradora de uma curiosidade por parte do narrador acerca da origem familiar, não pode ser compreendida e/ou interpretada como resultado do esquecimento, tendo em vista que "um passado que permanece mudo é muitas vezes menos o produto do esquecimento do que de um trabalho de gestão da memória segundo as possibilidades de comunicação" (POLLAK, 1989).

Observa-se, no conto "Violeta", uma espécie de acordo familiar entre aqueles que viveram no Uruguai e, supostamente, optaram por evitar as referências ao passado, como meio de preservar-se de recordações dolorosas. Para esses, o silêncio surge como maneira capaz de lhes proporcionar um sentimento de segurança e, além de possibilitar a acomodação a um novo ambiente social (Rio de Janeiro), pode representar a recusa em deixar que os fatos ocorridos no Uruguai como a prisão da tia Violeta "por conta das atividades ilegais do filho". As torturas a ela impostas, "sua cabeça nos galões d'água, os oficiais provocando ao despi-la” (CASTILLO, 2012, p. 243) e o assassinato de Miguel Angel, por estarem relacionados a momentos de sofrimentos extremos e pertencerem a um movimento social amplo, sejam enquadrados num tipo de relato mais amplo, tendo em vista que exigem "ancoragem numa memória" mais geral, a da sociedade uruguaia.

Apesar da profunda tristeza e ressentimento que esses fatos causaram aos membros da família de Miguel Angel, são exemplos que trazem à tona as crueldades praticadas pelo órgão de repressão do governo uruguaio durante o regime militar instaurado no país. O destaque maior é dado às circunstâncias da morte de Miguel, por atualizar uma ação que ofende a memória social, constituindo um ultraje à memória política e histórica uruguaia. Entretanto, ao ler o conto e a passagem em que tais circunstâncias são descritas, é impossível não rememorar outros regimes ditatoriais instaurados em países latino-americanos, onde ações semelhantemente cruéis foram praticadas:

Quando ingressou na Escola de Belas-Artes, Miguel Angel provavelmente não sabia o que lhe esperava, o golpe militar, a vida de revolucionário. No Chile, tornou-se chofer da embaixada da Finlândia e extraditava uruguaios com a ajuda da namorada finlandesa, a ditadura também por lá, imagino que foi por isso que se refugiou na Argentina, o Partido por La Victória Del Pueblo, a 
prisão. Dias depois seria colocado no segundo voo da morte: todos os presos políticos dentro do avião, a rampa de lançamento abrindo e logo todos no ar girando, o que ele pensaria naquele momento (na Violeta, na casa do Prado, na filha?) meu pai (CASTILLO, 2012, p. 245).

Com o assassinato de Miguel Angel, o primo tupamaro, parte da família migra para o Brasil. Nas lembranças de infância do narrador, Miguel Angel não se inclui. Entretanto, Violeta, sua mãe, a quem o narrador costumava visitar no Uruguai, é presença constante. Apesar disso, ela ainda permanece para ele como um enigma a ser decifrado:

Quem era a Violeta? Penso nisso enquanto caminho pelo jardim frontal daquela casa no Prado, onde ela e o marido viveram colados com meus avós, e a Marta, filha da Violeta, nos fundos com os gêmeos. Acho que se conhecemos alguém apenas quando crianças, a memória que temos dessa pessoa fica diferente. Como se não a tivéssemos conhecido o suficiente e faltasse saber algo que uma criança teria sido incapaz de compreender. E que vem a existir quando alguém, anos depois, nos conta sobre ela (CASTILLO, 2012, p. 249).

Isso ocorre porque nas lembranças que ele tem da tia a dor não está denunciada. Recorda-se de uma mulher vigorosa, alegre e presente que, enquanto à avó cozinhava, "ficava na mesa com a gente, dando risada e contando algum chiste". Uma mulher que adorava brincar de "medir o braço" com ele e que tinha uma risada silenciosa, a qual permaneceu registrada em sua memória visual:

Depois o começo do alzheimer, o silêncio cada vez maior. Então ela apenas sorria, não gargalhava mais. Causava-me uma impressão muito forte essa risada silenciosa, parecia querer rir de algo, mas não lembrava exatamente do quê. Conservou por isso o sorriso no rosto, e assim nos olhava quando chegávamos por lá.

No dia em que faleceu não pude ir ao Uruguai. Meu pai, sim, ligou de lá muito triste. Acho que, se eu tivesse ido, teria pedido que a maquiassem de modo que seus lábios formassem esse sorriso. Seria o ápice da risada silenciosa (CASTILLO, 2012, p. 249).

Observa-se que, para o narrador, o sorriso de Violeta sempre foi portador de significado muito amplo, indício de algo que só se tornaria compreensível 
a partir do momento em que os fatos passados lhes são revelados pelo pai, personagem ativa do passado e do presente que fecha e abre os álbuns de recordação: "meu pai fechando o álbum, guardando-o de volta no armário [...] Meu pai abrindo os álbuns, o colégio militar, a vergonha" (CASTILLO, 2012, p. 247-248).

Esse abrir e fechar de álbuns e a referência ao armário são indicativos de uma memória que a princípio é silenciada. O colégio militar, tipo de instituição em que o pai e ele próprio estudaram, remete a um sentimento de vergonha que é explicitado no conto, por intermédio de um exame nostálgico e de certo modo doloroso das lembranças. Tal sentimento permeia não apenas a lembrança do narrador, mas a memória de todos aqueles que de algum modo estiveram ou estão inseridos nesse passado, em que os fatos ocorridos constituem inquestionavelmente vestígios da história social uruguaia.

\section{Considerações finais}

Conforme os apontamentos realizados nos contos "Animais", de Michel Laub e "Você tem dado notícias?", de Leandro Sarmatz, os vestígios de fatos históricos também estão aludidos em menor e/ou maior grau. Mas, enquanto no primeiro tais vestígios são, ainda que distantes das realidades e das experiências vivenciadas pelo narrador, aceitos por ele como herança, no segundo, eles são causadores de opressão: são laços de uma história e/ou de tradições recusada pelo narrador protagonista.

Nesses contos e em "Violeta", de Miguel de Castillo, as modalidades do ato de fazer memória (a rememoração e a memorização) dão impulso à narrativa, incluindo no processo de atualização do passado, fatos contados por terceiros, principalmente pelos progenitores. Tais fatos são reconstruídos e interpretados nesses contos pelo narrador. Assim, o discurso memorialístico apresentado é influenciado pelo mundo que cicunda aquele que relata os fatos.

Os três contos constituem, portanto, história e explanações de memórias divergentes entre si, aqui aproximados pelo desejo de estudar o discurso memorialístico em narrativas contemporâneas que apresentassem, de algum 
modo, alusão a um passado histórico, ou melhor, a vestígios de fatos históricos, tendo em vista que tais fatos, quando presentes em narrativas de memória, possibilitam o "registro" de lembranças que normalmente ultrapassa o limite da recordação individual e, de algum modo, remetem o leitor para um imaginário coletivo, ou melhor, para elementos presentes em "registro" de memória coletiva.

\section{REFERÊNCIAS}

ALTMAN, Max.HojenaHistória:1973-GolpemilitariniciaditaduranoUruguai. Disponível em: <http://operamundi.uol.com.br/conteudo/noticias/13050/ hoje+na+ historia+1973++golpe+militar+inicia+ditadura+no+uruguai. shtml >. Acesso em: 25 set. 2014.

CHAUÍ, Marilena. Convite à Filosofia. 12. ed. São Paulo: Ed. Ática, 2002.

CASTILLO, Miguel Del. Violeta. Granta, 9: Os melhores jovens escritores brasileiros. Rio de Janeiro: Objetiva, 2012, p. 243-249.

ELIAS, Norbert. A sociedade dos individuos. Trad. Vera Ribeiro. Rio de Janeiro: Jorge Zahar, 1994.

ENCICLOPÉDIA do Holocausto. Disponível em: <http://www.ushmm.org/ wlc/ptbr/ article.php?ModuleId=10005143>. Acesso em: 30 out. 2014.

LAUB, Michel. Animais. Granta, 9: Os melhores jovens escritores brasileiros. Rio de Janeiro: Objetiva, 2012, p. 13-23.

LÉVY, Pierre. As tecnologias da inteligência: o futuro do pensamento na era da informática. Rio de Janeiro: Editora 34, 1993.

MAIER, Charles S. A meia-vida do nazismo e do stalinismo. Trad. Clara Allain. Disponível em: <http://www1.folha.uol.com.br/fsp/mais/fs1404200203. htm>. Acesso em: 24 set. 2014.

MARENALES, Julio. Uruguay: breve historia del movimiento de liberación nacional - Tupamaros. Disponível em: <http://www.latinamericanstudies. org/uruguay/tupamaros-historia.htm>. Acesso em: 08 out. 2014. 
POLLAK, Michael. Memória, esquecimento, silêncio. Trad. Dora Rocha Flaksman. Disponível em: <http://www.uel.br/cch/cdph/arqtxt/Memoria_ esquecimento_silencio.pdf $>$. Acesso em: 24 set. 2014.

RICOEUR, Paul. A memória, a história, o esquecimento. Trad. Alain François. et al. Campinas: Editora da Unicamp, 2007.

SARLO, Beatriz. Tempo passado: cultura da memória e guinada subjetiva. Trad. Rosa Freire d'Aguiar. São Paulo: Companhia das Letras; Belo Horizonte: UFMG, 2007.

SARMATZ, Leandro. Você tem dado notícias? Granta, 9: Os melhores jovens escritores brasileiros. Rio de Janeiro: Objetiva, 2012, p. 213-229. 